\title{
Supportive Beliefs: Why Should Teachers Understand their Nature and Role?
}

\author{
Crenças de Sustentação: Por Que os Professores Devem \\ Compreender a sua Natureza e Função?
}

\section{Maria Raquel BAMBIRRA* Laura MICCOLI**}

\begin{abstract}
Assuming the demands of educating teachers for classroom practice, it is high time researchers investigated beliefs in action deeper. Rokeach's (1968a, 1968b) concepts of central and peripheral values as gradient for discussing and defining the nature of beliefs, among the contribution of others, have provided Applied Linguistics with a gateway to study the dynamics of belief change. Framed by these studies and the results of a doctoral study on autonomy development, this paper aims at acknowledging a third element into the gradient: supportive beliefs, which for their content, nature and role in human cognition refer to beliefs that cannot be considered peripheral. We present evidence that some currently considered peripheral beliefs are, in fact, supportive beliefs, whose existence protects central beliefs from being banned from cognition whenever challenged. Data to support such claim were collected from a written narrative and a series of five interviews with a 45 year-old woman, taking an intermediate level English course in Brazil, as part of a larger case study. During the interviews, some of this woman's beliefs were challenged. We discuss how she defended, maintained, modified or totally discarded them and refer to the difficulty of changing beliefs due to their emotional and/or cognitive relevance.
\end{abstract}

Key-words: Beliefs in action. Beliefs cognitive role. Supportive beliefs.

* Doutorado em Estudos Linguísticos pela Universidade Federal de Minas Gerais (2009). Professor do Ensino Básico, Técnico e Tecnológico do Centro Federal de Educação Tecnológica de Minas Gerais. Contato: raquelbambirra@gmail.com.

** Doutorado em Educação pela University of Toronto, Canadá (1997). Professor da Universidade Federal de Minas Gerais. Contato: miccoli.laurastella@gmail.com. 
Resumo: As demandas da formação de professores para a prática pedagógica exigem um aprofundamento nas investigações sobre crenças em ação. Os conceitos de crenças centrais e periféricas de Rokeach (1968a, 1968b), enquanto um gradiente para a compreensão da natureza das crenças, abrem caminho para se estudar a mudança de crenças em Linguística Aplicada. Com base nesse e em outros estudos e nos resultados de uma tese de doutorado sobre desenvolvimento de autonomia, este artigo busca reconhecer um terceiro elemento no gradiente: as crenças de sustentação, as quais, em função de seu conteúdo, natureza e função na cognição humana, revelam ter um papel distinto daqueles das centrais ou das periféricas. Apresentamos dados coletados por meio de uma narrativa de aprendizagem e de cinco entrevistas realizadas com uma mulher de 45 anos cursando o nível intermediário de um curso de inglês no Brasil ao longo de três semestres. Discutimos como a estudante defendeu, manteve, modificou ou descartou crenças e identificamos, dentre elas, crenças de sustentação, cujo papel é proteger crenças centrais, evitando que estas sejam banidas da cognição quando desafiadas. Concluímos com a dificuldade de se mudar crenças devido à sua relevância emocional e/ou cognitiva.

Palavras-chave: Crenças em ação. Função cognitiva das crenças. Crenças de sustentação.

\section{Introduction}

Among the many demands that English as a Second Language (ESL) teachers face in classrooms, beliefs seem to play a significant role in students' performance for good or bad. Nonetheless, researchers' investigation of beliefs has only scratched the surface towards helping teachers deal with the challenges modulated by the extensive list of beliefs documented in the ESL literature. This paper aims to bridge that gap by presenting a piece of research that has investigated beliefs beyond the goal of description to explain performance. Aiming deeper, the goal was to understand how beliefs hinder or promote learning. The findings point to a new type of belief whose nature and role should be understood by teachers, if they are to help students overcome those beliefs that may hinder their learning development.

Such endeavor is framed by, among others, Rokeach's (1968a) concepts of central and peripheral values as a gradient for discussing and defining the 
nature of beliefs. According to Rokeach, central beliefs relate to our selfconceptions, sense of self-esteem, and reality, whereas peripheral beliefs encompass any other content. Such typology has provided Applied Linguistics with a gateway to study the dynamics of belief change - a phenomenon documented in a year-long case study on a learner's experience towards autonomy development (BAMBIRRA, 2009). Data were collected from a written narrative and a series of five interviews with a 45 year-old woman, taking an intermediate level English course in Brazil. During the interviews, some of this woman's beliefs were challenged, following Rokeach's method of value self-confrontation. The data we present in this paper provides evidence that some currently considered peripheral beliefs have, in fact, a supportive role. They protect central beliefs from being banned from cognition whenever challenged, and, consequently, hinder belief change.

Thus, in this paper, we discuss how the participant defended, maintained, modified or totally discarded beliefs as well as explain her difficulty in changing beliefs due to their emotional and/or cognitive relevance. We claim that there must be a differentiation among peripheral beliefs within Rokeach's model and argue for the recognition of a different type of belief within Rokeach's (1968a) from central to peripheral belief dimension, pointing to the need to expand the typology with a third element into the gradient: supportive beliefs, which for their content, nature and protective role in human cognition refer to beliefs that cannot be considered peripheral.

Acknowledging the existence of this set of beliefs expands the understanding of the role beliefs play in learning ESL. It is also relevant for teachers who understand the importance of dealing with beliefs as central to changing learners' attitudes and behaviors so as to promote their ESL learning experiences.

\section{Cognitive Sciences: processing reality}

Kintsch e van Dijk (1978) cognitive processing model explains how we make sense of experiences (personal histories) as well as the stories we hear and/or read about. Their model is concerned with discursive semantic structures, demonstrating that beliefs are central to comprehension processes. Although comprehension is personal and unique, it is context-dependent and grounded on personal and general knowledge. Personal knowledge encompasses opinions, attitudes, ideologies, representations and sociocultural 
knowledge, socially shared beliefs. According to Kintsch e van Dijk (1978), general knowledge, together with situated personal beliefs, allows us to interact and act in a successful and meaningful way with other members of our culture because beliefs subsidize comprehension - the process of making coherent inferences of people's discourse, i.e., understanding and being understood.

Comprehension involves attention, consciousness, decision-making and memory. Van Dijk (2008) explains that our long-term memory stores subjective interpreted experiences through creating specific mental models, each bearing a proper schematic structure. These mental models include our personal knowledge, together with socially shared beliefs. Most part of interaction and discourse is processed from such mental models. In other words, understanding is possible due to the construction of mental models from personal opinions and emotions about events experienced, heard or read about. Once constituted, these mental models are stored in long-term memory, where they become part of a network basis for the acquisition of future memories, beliefs and additional knowledge deriving from experience.

\section{Psychology: the organization and role of beliefs in human cognition}

Accounting for the organizational structure of beliefs in human cognition, Rokeach (1968a) proposed his belief system theory ${ }^{1}$, which states that beliefs interrelate to one another in systems of beliefs according to semantic criteria. Within belief systems, there are countless sub-systems of values, attitudes and behaviors in which personal and social beliefs are functionally and cognitively connected to one another, interrelated, and so interdependent.

The main principle of his model is centrality. In other words, beliefs are organized along central-peripheral dimensions of importance. Our selfconceptions, i.e., the ideas we have about morality and competence occupy the central position. Once centrality holds a direct correlation with interconnectedness (GRUBE; MAYTON; BALL-ROKEACH, 1994), we can assume that our self-conceptions are central beliefs, which are functionally

${ }^{1}$ See also Green (1971), Pajares (1992), Benson e Lor (1999), Woods (1996; 2003), Barcelos (2007). 
and cognitively interconnected to other beliefs. The elements of such belief system, hierarchically considered from more to less central, include: terminal values, instrumental values, attitudes and behaviors. Figure 1 shows a representation the organization of this belief system.

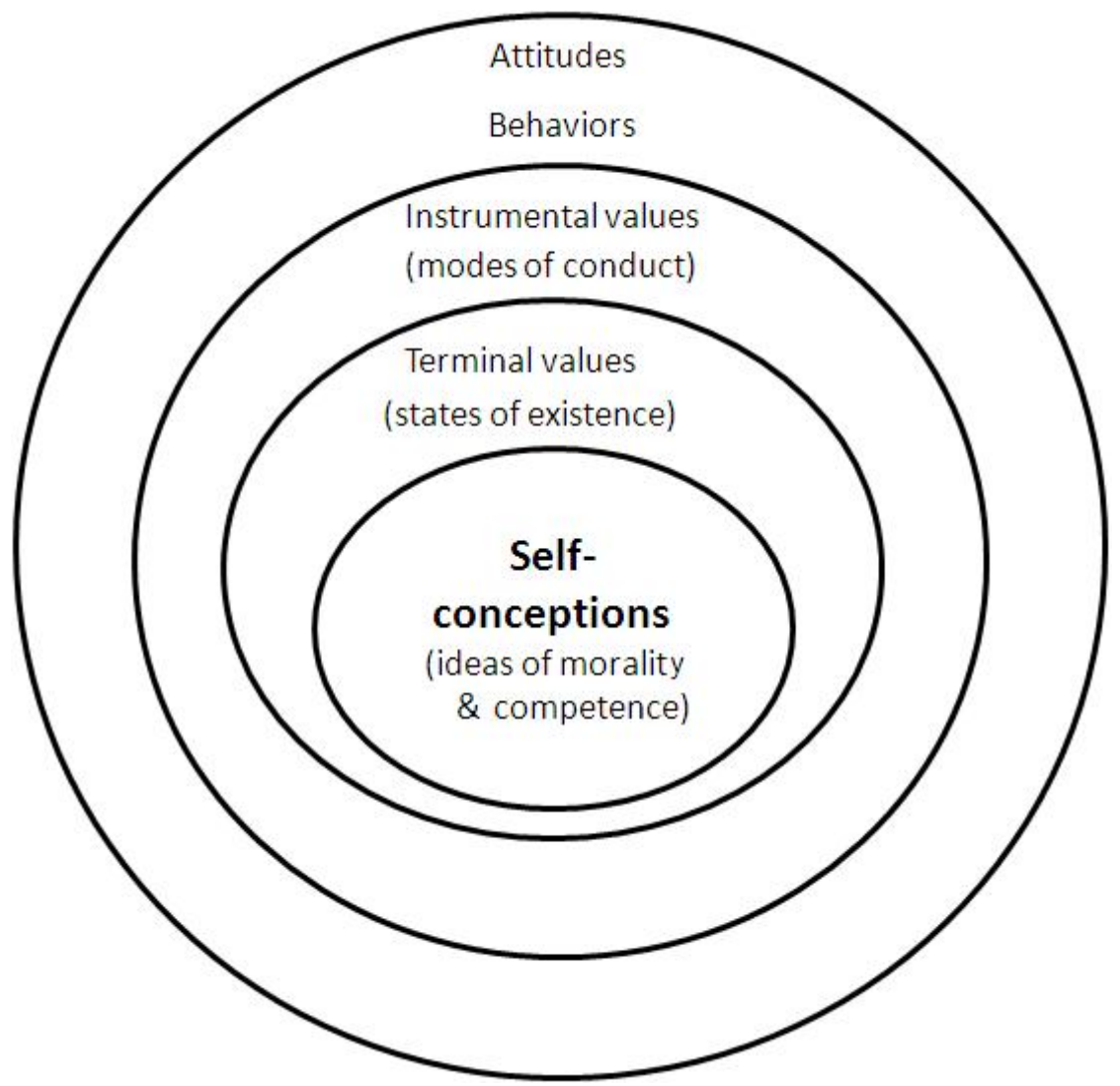

Figure 1 - Rokeach's data Belief System

Figure 1 presents a representation of the different nature of beliefs with the centrality of self-conceptions, protected by terminal values, instrumental values, behaviors and attitudes, all of them peripheral in relation to self-conceptions. Grube, Mayton and Ball-Rokeach (1994, p. 155) define values as "translations of individual needs into a socially acceptable form that 
can be presented and defended publicly". Terminal values represent states of existence while instrumental values represent modes of conduct. In other words, instrumental values represent means to attain terminal values and, for this reason, they are more central than the instrumental. In addition, Rokeach e Kliejunas (1972) claim that terminal values can function as means for the attainment of other terminal values. In this case, the hierarchical order of centrality between the two kinds of terminal values is determined functionally. An attitude refers to an enduring organization of beliefs about objects, such as persons, things or single ideas. In his theory, beliefs are context-dependent, referred to as situations, circumstances or events (ROKEACH, 1966), in other words, the sociocultural context. Behavior is a function of at least two interacting attitudes: one towards the object and the other towards the situation (ROKEACH; KLIEJUNAS, 1972). On the one hand, changing attitudes means causing impact on functionally connected attitudes and on a limited set of behaviors. On the other hand, changing a central belief impacts on the whole belief system, not a common occurrence, once the level of interconnectedness of beliefs within the sub-systems is high (GRUBE; MAYTON; BALL-ROKEACH, 1994).

According to Rokeach (1966), any attitude change comprises a shift in the organization, structure and/or content of one or more beliefs in the attitude sub-system. Attitudes are expressed by means of opinions (verbally or non-verbally) and/or behaviors. Behavioral changes are determined by shifts toward objects or situations or both.

An important principle is that of belief congruence $\mathrm{ROKEACH}$; ROTHMAN, 1965). This principle states that a belief, a sub-system or even a system of beliefs must be congruent with one's own belief system to be valued. Otherwise, they are simply discarded. Thus, we evaluate people proportionally to the degree of congruence among their beliefs and our own.

Belief evaluation happens as a process of paired comparison called cognitive interaction. Two stimuli, each having its separate meanings, are compared, and an evaluative meaning emerges. This comparison is what determines their degree of congruence. In other words, when two beliefs of the same importance are being compared, the one that holds more similarity to our belief system is considered more congruent. In the same way, when two beliefs are perceived as similar, the one that seems more important to us is considered more congruent (ROKEACH; ROTHMAN, 1965). 
Rokeach (1968b) devised a mechanism to promote or facilitate belief change. Understanding this mechanism requires addressing the basic premises of the belief system theory, which postulates there is a human need for consistency among beliefs and behaviors. Belief and behavior change constitute a basic impetus to balance and even enhance our positive selfconceptions - ideas of morality and competence. Thus, central beliefs are to be protected by values that determine attitudes and behaviors. Rockeach also postulates that we constantly submit what we have just said or done to self-evaluative processes in order to judge their consistency to our selfconceptions - first towards self-esteem and then towards reality.

According to Rockeach (1968b), a state of cognitive inconsistency is the necessary condition for belief change. Although normally there are inconsistent elements in our belief system on a temporal, exceptionally, or even on a permanent basis (ROKEACH, 1965), an incongruity among beliefs creates a psychological pressure for self-evaluation that may lead to belief change. According to Grube, Mayton e Ball-Rokeach (1994), for this to happen, Rokeach developed the method of value self-confrontation to trigger changes or enhance stability in values, beliefs, attitudes, and behaviors, involving the following steps: (1) self-confrontation of specific values (preferably over attitudes or behavior) - induced by paired comparison or aroused naturally due to any existing level of belief inconsistency; (2) recognition of a state of self-dissatisfaction regarding specific performance; and (3) decision for belief maintenance, belief change or belief discard.

On the one hand, belief change does not imply a change of expressed opinion or behavior. Public conformity or compliance and private acceptance must be equalized so that a belief change can be completely manifested. On the other hand, a shift in expressed opinion or behavior does not necessarily reflect belief change. Again, personal and contextual variables are to be analyzed before diagnosis (ROKEACH, 1966). The method of value selfconfrontation postulates that values change because they are more central than attitudes and behavior, which, once changed, promote broad changes to all cognitively and functionally related values, attitudes and behaviors.

According to Rokeach's belief system theory, unlike attitudes, values are the criteria for guiding action, defining or maintaining attitudes, evaluating, judging and justifying one's own and others' actions and attitudes as well as criteria for comparing oneself to others (ROKEACH, 1968a). Thus, they should be the sources of confrontation for belief change. 


\section{The Study}

A case study on the autonomy development experiences of seven adult students over the course of a year and a half in an intermediate level English Extension Course offered at a Federal University in Brazil is the context from which emerge the experiences of a 45-year old woman that are presented in this paper. Data come from one written narrative and five transcribed reflection sessions, documenting the learner/participant's learning experiences and her effort to develop autonomy in language learning framed by Dörnyei's (2001) process motivation model.

The learner answered five questionnaires on learning styles ${ }^{2}$, learning strategies $^{3}$, learning motivation (BAMBIRRA, 2009), use of self-regulation strategies (BAMBIRRA, 2009) 4 and level of digital literacy with affiliation to imagined communities (BAMBIRRA, 2009). She also wrote a narrative explaining how she had learnt English up to that moment. The data from these instruments subsidized the researcher in elaborating a learning profile ${ }^{5}$ to guide the subsequent data collection procedures, which included reflection sessions with the learner to discuss her learning experiences and to support her during the process of trying to implement Dörnyei's (2001) process motivation model as the way to develop autonomy. These were tape recorded and later transcribed.

Along the data collection process, the participant was confronted with deeply rooted beliefs that stood in her way to meet the learning goals she herself had established for autonomy development. It became clear that these beliefs were hampering her. The researcher, as a coach, tried to help, making sure that the participant was aware of her beliefs, and also of how they hindered her attempts to be more autonomous. Through coaching, the researcher helped her challenge these beliefs one by one, looking for alternative ways to achieve success in her endeavors.

The results were rewarding for participant and researcher. Some of the hampering beliefs were partially changed; others totally changed. The

2 Index of learning styles questionnaire: < http://www.engr.ncsu.edu/learningstyles/ ilsweb.html > (FELDER e SOLOMON, 2006).

${ }^{3}$ Language learning strategies questionnaire (OXFORD, 1990).

${ }^{4}$ Based on Dörnyei (2001; 2005).

${ }^{5}$ From this learning profile, the representation of Figure 2 emerged. 
participant managed to increase her level of autonomy in language learning and felt more competent with an improved sense of self-esteem. In the process, belief change proved to be central for autonomy development. Thus, in this case, analyzing the data in the light of the theory previously revised advances the understanding of beliefs in action.

\section{Data Analysis}

In this section, we discuss how the most relevant beliefs were assessed, challenged and processed by the participant. From the tests taken prior to the beginning of the reflection sessions, many beliefs, which seemed to be deeply rooted, emerged. Figure 2 shows the organization of this 45-woman learner/participant's beliefs, categorized as central or peripheral. The participant dealt with this representation along the data collection process, where the three largest oval shapes represent the central beliefs, namely: (1) Old parrots never learn how to speak well; (2) I can only learn if somebody teaches me; and (3) To speak English is to have native speakers' communicative competence. All the other shapes represent peripheral beliefs.

In Figure 2, the three larger central beliefs are represented with no specific line pattern since no particular relationship between central and peripheral beliefs had been identified yet. The smaller oval shapes represent what Green (1971) would call derivative beliefs, but Rokeach (1968) called them peripheral beliefs.

The participant was presented with Figure 2 in the first interview as a synthesis of the results of all the tests she had taken in preparation for the reflective sessions that would document her autonomy development in class. As expected, the three central beliefs illustrated in Figure 2 emerged naturally during discussions and the participant agreed with their existence. At the end of this first session, she established one long term goal: to improve her speaking skills in English, and four short term objectives which would be instrumental to attain her main goal in due time: (1) invest on speaking while in class, (2) practice maintaining a discussion, even in Portuguese, (3) pay more attention to intonation, and (4) imitate the teacher's intonation. Notice that the main goal aimed at one of her hampering central beliefs - old parrots never learn how to speak well. 


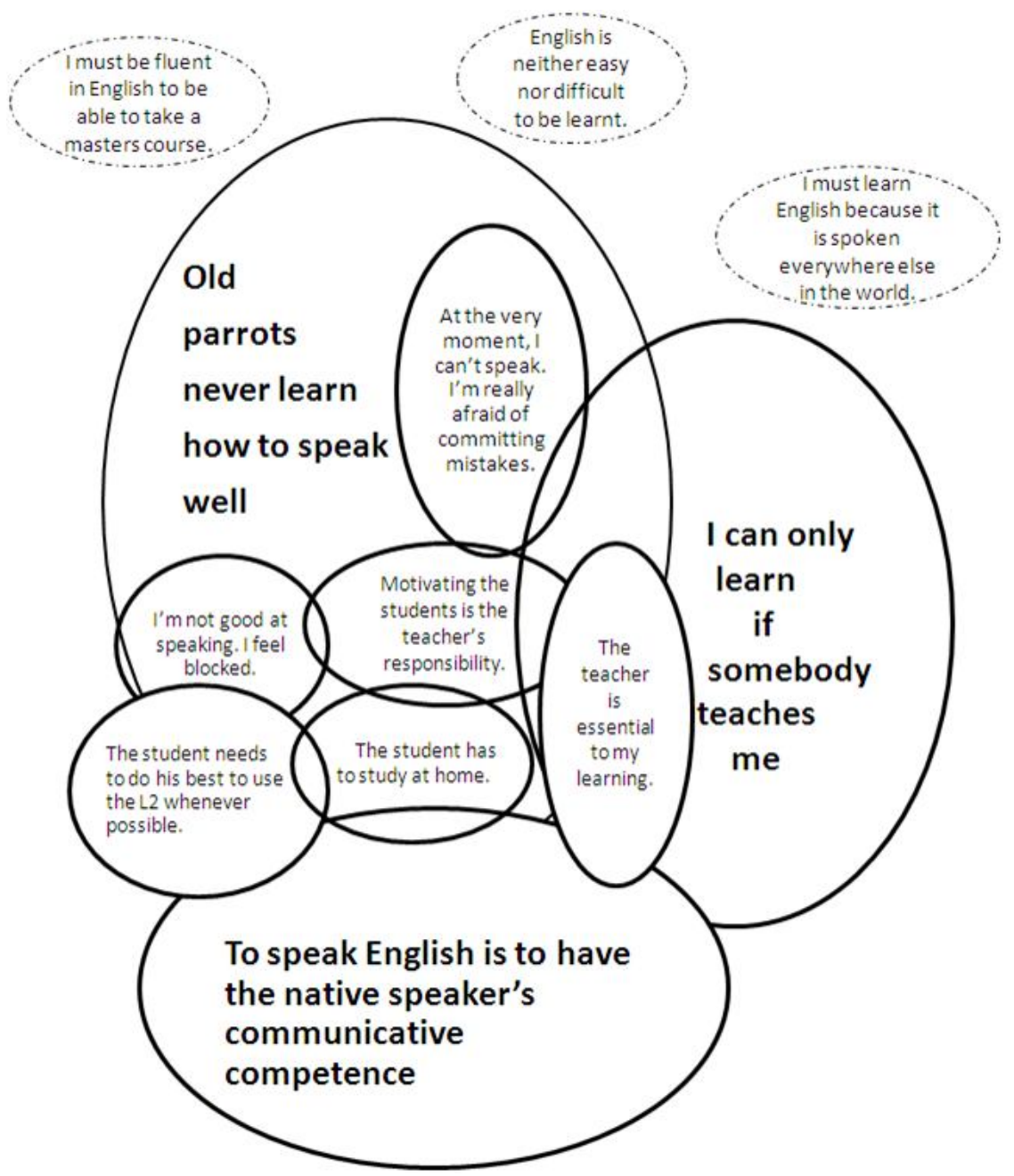

Figure 2 - Participant's initial central and peripheral beliefs

From then on, in all reflective sessions the learner/participant would narrate and reflect about her learning experiences, analyzing to what extent she managed to accomplish the objectives she had established. Soon she realized that things did not happen as she expected, causing her anguish. Coaching was necessary to bring the three central beliefs into awareness. 
Due to limitations of space, the participant's trajectory towards autonomy is recounted without illustrative data excerpts, available in Bambirra (2009).

During the second reflective session, the participant reported she was trying to speak more in class (supportive beliefs: I need to practice speaking/ I am not good at speaking), but without receiving any of the expected teacher correction, which frustrated her (supportive beliefs: motivating the students is the teachers' responsibility). She believed she had to be corrected to learn (supportive belief: teachers must correct their students on the spot). The researcher argued against such belief, referring to the intelligibility criterion (JENKINS, 2000), which was not enough. The learner argued that she had been unsuccessful in a recent oral test, although the teacher had given her a good grade. The researcher/coach asked her if she could explain that. She answered that the test content was easy, but at the very moment she had to speak, she could never remember the correct word to use (supportive belief: I get blocked). She tried to paraphrase, but her performance was not satisfactory (central belief: old parrots never learn how to speak well). After some time, the participant mentioned she had also taken a written test, and, differently from the oral test, her grade had been excellent (supportive belief: Learning grammar and vocabulary is easier than developing listening and speaking skills.). Once she had been successful in the written test, it was reasonable to suppose she was a good student, doing well in her learning and in her tests (use of the value self-confrontation method). The researcher/ coach insisted on getting an explanation for the belief of having been unsuccessful in the oral test in spite of the good grade. She explained that she had gotten a good grade because the teacher knew her from a time in which she had been an excellent student. Still incapable of solving the incongruity among central and supportive beliefs, that was her only possible answer. Either she needed to undergo more of the self-evaluative process before a belief change happened or she would come up with another supportive belief to explain this cognitive inconsistence.

This example illustrates that the central - peripheral dichotomy does not work. The participants' explanations document that many supportive beliefs were activated to protect her central belief of difficulty to learn English because of her age (old parrots never learn how to speak well). Whenever a supportive belief is deconstructed - its inconsistence with one's self-conceptions is clear and the reaction is to substitute it for another supportive belief to protect the content of the central belief previously 
supported. This process only comes to an end when a belief change takes place.

Another example of the participant's effort to protect a central belief comes with the belief: to speak English means to acquire the native speaker's communicative competence. During data collection, she had three teachers. The first teacher $(\mathrm{T} 1)^{6}$ was a Brazilian, whom the participant questioned her teaching approach. The second teacher $\left(\mathrm{T}^{2}\right)^{7}$ had been raised in London and had lived in four different English-speaking countries before moving to Brazil to begin her undergraduate studies in Language Arts. The participant thought she would be perfect because her English was native-like. In the beginning, she was happy she would have classes with T2, whom she had nicknamed the 'multicultural teacher'. Soon the participant realized that, despite her excellent English, T2 was not a better teacher than T1.

When T1 was the teacher, the informant complained that (1) she never corrected her pronunciation mistakes (supportive belief), that (2) she would not force the students to interact in English (supportive belief about teacher's responsibility), that (3) she would speak too much Portuguese in class (supportive belief: teachers must speak only English in class), (4) her classes were teacher-centered and she wouldn't control her timing (supportive belief: learning English requires practice), (5) that she would never ask the students to repeat words and sentences to practice oral language (supportive belief: English is better learnt through oral repetition), and that (6) her classes were too grammar bounded (supportive belief: Learning grammar and vocabulary is easier than developing listening and speaking skills). Parallel to that, the researcher/coach showed the participant that she could learn outside the classroom to promote her autonomy. To that end she was pointed to websites to practice English skills, which the participant eagerly visited. Besides the practice opportunities they provided and the resources to study for tests, she had fun with crosswords, word searches and pronunciation online.

The new technologies became a productive discovery. She not only managed to forget her dissatisfaction with T1 but also she started to realize that she was not dependent on the teacher to learn as she used to (central belief: I can only learn if somebody teaches me.). Nonetheless, she kept attributing to her teachers the responsibility for teaching her.

${ }^{6}$ T1 - The teacher she had during the first semester of data collection.

${ }^{7} \mathrm{~T} 2$ - The teacher she had during the second semester of data collection. 
In the second semester of data collection, the participant met a new teacher, T2. Her beliefs related to the myth of the native speaker ${ }^{8}$ were naturally challenged, but she found it hard to learn from T2. The participant complained her classes were frustrating because she hated the English T2 spoke, which she considered ugly. In addition, T2 would overcorrect her on the spot, mainly for pronunciation. She found herself repeating alternative pronunciation, even when hers was correct. Moreover, T2 spoke only English in class, and her sense of humor did not please the learner, although she used to defend that 'teachers must speak only English in class' and 'the best teachers are goofy and always deliver classes full of fun', both supportive beliefs. T2 also gave nicknames to every student, which bothered the participant and, according to the participant, spent much time talking about her experiences abroad. The researcher/coach asked if what she experienced with this new teacher was not exactly what she had always wanted. The participant replied she was not having fun; she was not interested in T2's life and also that she did not teach them well because she never explained grammar, she never used the blackboard or did repetition drills, and she was unable to have students interact with each other because they did not understand most of the things she said. In fact, the participant expected an audio-lingual teacher and T2 embraced the communicative approach. As there was much difference between T2's teaching approach and the participants' previous teachers', she could not even recognize what $\mathrm{T} 2 \mathrm{did}$ as teaching. This upset her so that she looked for the course coordination to formally complain about the T2's pedagogical practice.

It was the new teacher, T2, who forced the informant to undergo the self-confrontation method regularly. She began by comparing both T1 and T2 against her dissatisfaction with her classes, trying to find congruence among her beliefs and what she had been trying to learn. On her own, she realized that most of her complaints about T1 resulted from belief mismatches

${ }^{8}$ The myth of the native speaker in Brazil derives from the time when the audiolingual method was predominant in Brazil (from the 70's to the mid 80's). It comprises the universe of beliefs involving the assumed perfect linguistic communicative competence of native speakers of English. Among these beliefs, the most common are: 'to speak English means to acquire the native speaker's communicative competence' and 'the best teachers are natives or speak like natives'. 
between her own cognition and that of her teacher. She realized that being a native speaker was not enough to be a good language teacher (central belief). She became aware that a teacher did not have to be goofy or funny; on the contrary, it is important to lead a coherent and theoretically oriented pedagogical practice.

Because the participant had spent the whole semester accessing the internet to compensate for the poor learning she was having, she noticed that she was using more learning strategies in her favor; she was becoming good at planning and administering her time; she evaluated her needs and accomplishments quite well and, as a consequence, she had accomplished her short term objectives and real learning independently from T2 or anyone else. Such realization was the desired outcome for the autonomy development research project and had a special meaning for the participant. First, she developed a genuine feeling of how competent she was, which boosted her self-esteem. Second, it was decisive for a renewed conception of two of her major hindering central beliefs. One was partially changed - the one which sustained that she could only learn if someone taught her, and the other, which defended that learning English meant acquiring the native speaker's linguistic competence was discarded.

\section{Results}

Coaching the participant through her journey towards autonomy development revealed that autonomy is affected by the nature of learners' beliefs. In Figure 3, we present a revised version of the map of beliefs in Figure 2. Figure 3 refines the analysis of central and peripheral beliefs, displaying a belief sub-system on L2 learning by means of different line patterns - straight, broken and broken bold lines. The relationship between central and a set of beliefs, which, as the data analysis indicated, despite being generically called peripheral so far, demonstrated to be instantiations or manifestations of central beliefs, have been depicted with the same line pattern of their corresponding central belief.

These differentiated set of beliefs, represented in intersectional relation to central beliefs, are the ones we have named supportive beliefs, once they have a specific nature and role in cognition, namely, they protect the central belief from being challenged or discarded, as demonstrated in this paper. The others, those recognized as legitimate peripheral beliefs, have been maintained 
in this revised representation. They are the small oval shapes not touching any of the central beliefs. These beliefs should remain as peripheral because they did not influence or hamper the participant's learning in any way.

In Figure 3, we can see that the supportive beliefs protecting the central belief: 'Old parrots never learn how to speak well' are: (1) Anyone who is still young can learn English well; (2) 'Learning English grammar and vocabulary is easier than developing listening and speaking skills; (3) 'I am not good at speaking. I feel blocked'; (4) 'At the very moment, I can't speak. I am really afraid of committing mistakes'; (5) 'I don't know how to study for an oral test'; and (6) 'I can't evaluate myself'. The ones protecting: 'I can only learn if somebody teaches me' are: (1) 'To be motivated is very important to learn a L2'; (2) 'Motivating the students is the teacher's responsibility'; (3) 'The teacher is essential to my learning'; (4) 'Teachers should speak less so that students could speak more'; and (5) 'Students mispronunciation should be corrected on the spot'. At last, the supportive beliefs protecting the central: 'To speak English is to have the native speaker's communicative competence' are: (1) 'The student needs to do his best to use the L2 whenever possible'; (2) 'The student has to study at home'; (3) 'English is better learnt through oral repetition'; (4) 'Learning English requires practice'; (5) 'Teachers must speak only English in class'; (6) 'The student must actively participate in class activities'.

As the data demonstrated, central, supportive and peripheral beliefs are interconnected in semantic networks. Nonetheless, while central beliefs are content-specific, supportive and peripheral beliefs can encompass any sort of content. Moreover, there is a hierarchical relation among central and peripheral beliefs, as so defined by Rokeach (1966). Yet, there seems to be no hierarchy among central and supportive beliefs. Thus, just like with central and peripheral beliefs, supportive beliefs can also constitute unconscious content. 


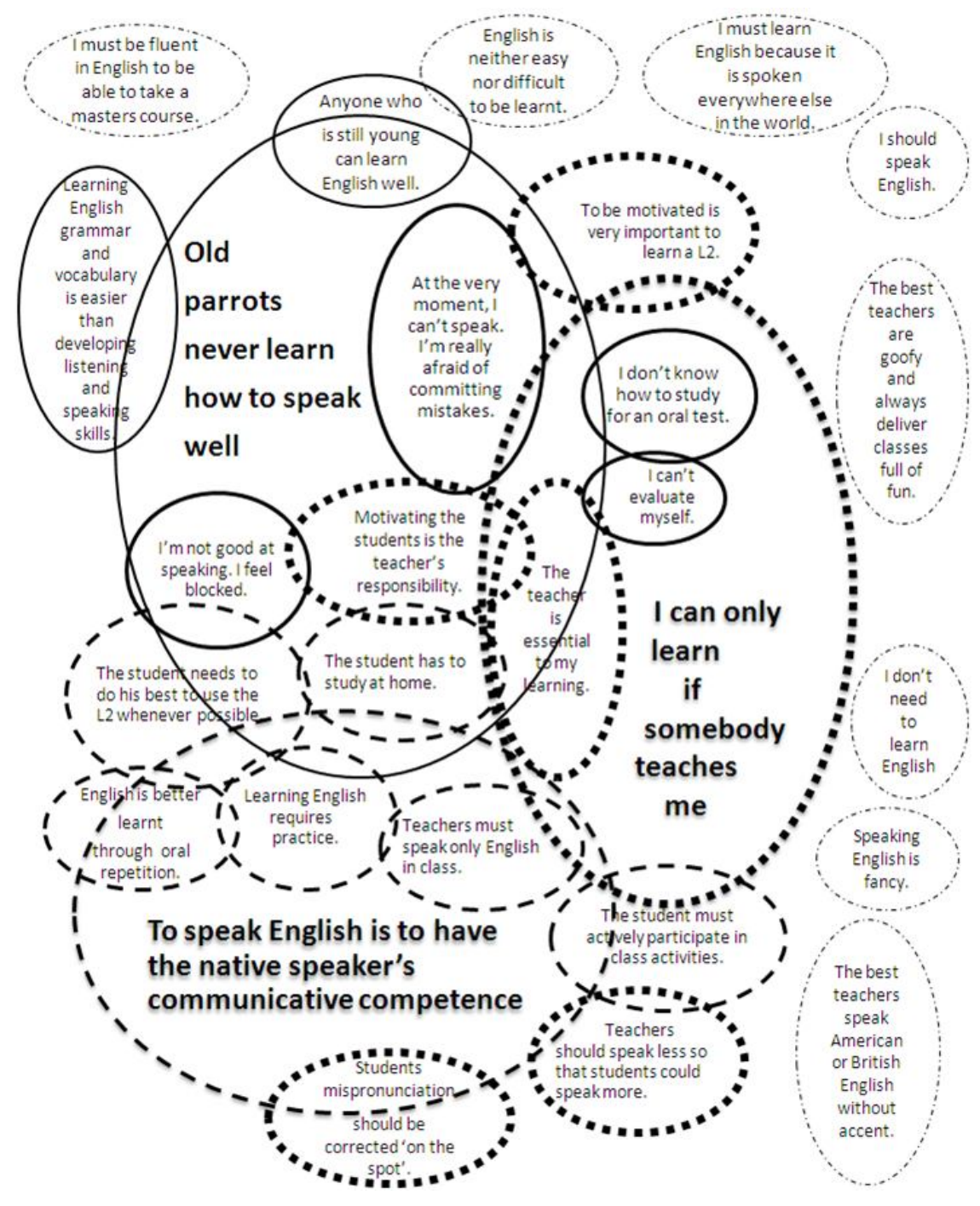

Figure 3 - Participant's documented beliefs sub-systems 


\section{Conclusion}

In this paper we have reviewed the organization of beliefs in human cognition, documenting how Rokeach's (1968a) belief system theory as well as the value self-confrontation method (ROKEACH, 1968b) are well known in the terrains of Psychology, where they have been discussed, tested and used for decades. They were suitable to explain the phenomena discussed, and surely deserve further research within Applied Linguistics. Such an agenda might have a double fold aim: expand the understanding of how beliefs might affect learning as the student/participant data here presented have documented as well as illuminate the understanding of teachers' cognition from a focus on their beliefs in action. These initiatives may bring similar results to those in this study: from the student's perspective, as demonstrated, understanding the nature of beliefs promoted an awareness that guided the learner through a journey of confrontation towards overcoming selfimposed beliefs. From the teachers' perspective, a study with similar focus might lead to the review of beliefs about teaching with potential implication for ESL teaching and learning.

We have also advocated that, within Rokeach's central-to-peripheral belief dimension (ROKEACH, 1968a), supportive beliefs should be acknowledged due to their specificities related to their nature and role and also to the potential they present to inform any research involving beliefs in action.

An implication of this study points to researchers, who should be able to recognize supportive beliefs and isolate them from other peripheral beliefs within a belief sub-system. Supportive beliefs are central to the study of beliefs in action. If the objective is to facilitate belief change, supportive beliefs should be used to challenge central beliefs. As the results of this study have demonstrated, it is useless to challenge supportive or peripheral beliefs. As Rokeach (1966) made clear, values (central beliefs) should be addressed instead. They are the ones responsible for orienting self-evaluation processes leading to effective change. More research with such a goal are needed.

Finally, teachers and prospective teachers should know the role beliefs play in the ESL learning process as well as understand the importance of making students aware of their belief systems. Together, teacher and students might find a way to confront those beliefs that might be hindering their learning process, with potential benefits for both. 


\section{References}

BAMBIRRA, M. R. A. Desenvolvendo a autonomia pelas trilhas da motivação, autoestima e identidade: uma experiência reflexiva. 2009. Tese (Doutorado em Letras) - Universidade Federal de Minas Gerais, Belo Horizonte. 2009.

BARCELOS, A.M.F. Reflexões acerca da mudança de crenças sobre ensino e aprendizagem de línguas. Revista Brasileira de Lingüistica Aplicada, v. 7, n. 2, p. 109-38, 2007.

BENSON, P.; LOR, W. Conceptions of language and language learning. System, n. 27, p. 459-472, 1999.

DÖRNYEI, Z. Motivation to learn a foreign/second language. Teaching and researching motivation. Harlow: Longman, p. 46-100, 2001.

DÖRNYEI, Z. The psychology of the language learner: individual differences in second language acquisition. New Jersey: Lawrence Erlbaum, 2005.

FELDER, R.; SOLOMON, B.A. Index of learning styles questionnaire. 2006. Available at: <http://www.engr.ncsu.edu/learningstyles/ilsweb.html>. Accessed from Jul. 2006 to May. 2008.

GREEN, T. E. The activities of teaching. New York: McGraw Hill, 1971.

GRUBE, J.; MAYTON, D.; BALL-ROKEACH, S. J. Inducing change in values, attitudes and behaviors: belief system theory and the method of value self-confrontation. Journal of Social Issues, v. 50, i. 4, p. 153-173, 1994.

JENKINS, J. The phonology of English as an international language. Oxford: Oxford University Press, 2000.

KINTSCH, W.; VAN DIJK, T.A. Toward a model of text comprehension and production. Psychological Review, v. 85, n. 5, 1978.

OXFORD, R. Language learning strategies: what every teacher should know. Boston, MA: Heinle e Heinle, 1990.

PAJARES, M. F. Teacher's beliefs and educational research: cleaning up a messy construct. Review of Educational Research, v. 62, n. 3, p. 307-332, 1992. 
ROKEACH, M. Attitude change and behavioral change. The Public Opinion Quarterly - JTSOR, v. 30, issue 4, 1966. p. 529-550.

ROKEACH, M. Beliefs, attitudes, and values: a theory of organization and change. San Francisco: Jossey-Bass, 1968a.

ROKEACH, M. A theory of organization and change within valueattitude systems. Journal of Social Issues, v. 24, n. 1, p. 13-33, 1968 b.

ROKEACH, M.; KLIEJUNAS, P. Behavior as a function of attitude toward object and attitude toward situation. Journal of Personality and Social Psychology, v. 22, i. 2, p. 194-201, 1972.

ROKEACH, M.; ROTHMAN, G. The principle of belief congruence and the congruity principle as models of cognitive interaction. Psychological Review, v. 72, i. 2, p. 128-142, 1965.

VAN DIJK, T. A. In: HOFFNAGEL, J.; FALCONE, K. (Orgs.) Discurso e poder. São Paulo: Contexto, 2008.

WOODS, D. Teacher cognition in language teaching: beliefs, decision-making, and classroom practice. Cambridge: Cambridge University Press, 1996.

WOODS, D. The social construction of beliefs in language classroom. In: KALAJA, P.; BARCELOS, A. M. F. (Orgs.). Beliefs about SLA: new research approaches. Dordrecht: Kluwer, 2003. p. 201-229. 